\title{
EVIDENCE OF Leishmania (Leishmania) infantum INFECTION IN DOGS FROM JUIZ DE FORA, MINAS GERAIS STATE, BRAZIL, BASED ON IMMUNOCHROMATOGRAPHIC DUAL-PATH PLATFORM (DPP ${ }^{\circledR}$ ) AND PCR ASSAYS
}

José Geraldo CASTRO-JÚNIOR(1), Mariana Lourenço FREIRE(2), Samantha Priscila Silva CAMPOS(2), Kezia K.G. SCOPEL(2), Renato PORROZZI(3), Edimilson Domingos DA SILVA(4), Fabio A. COLOMBO(5), Rita de Cássia Viveiros da SILVEIRA(5), Marcos José MARQUES(5) \& Elaine Soares COIMBRA(2)

\begin{abstract}
SUMMARY
In Brazil, domestic dogs are branded as the primary reservoir for zoonotic visceral leishmaniasis, due to the clear positive correlation observed between human and canine infection rates. This study aimed to carry out a serological survey of canine visceral leishmaniasis (CVL) in dogs housed at a public kennel in the municipality of Juiz de Fora, Minas Gerais State, Brazil, using the immunochromatographic TR DPP ${ }^{\circledR}$ CVL rapid test. Additionally, conventional and/or real time PCR assay was used to detect and confirm L. infantum infection in the DPP positive dogs only. Of the $400 \mathrm{dogs}$ studied, most did not present clinical signs for CVL $(p<0.05)$, and fifteen $(3.8 \%)$ were seropositive in the DPP test. There was no statistically significant difference between the DPP seropositive dogs and the clinical signs of the disease $(p>0.05)$. Both conventional and real time PCR tests confirmed $L$. infantum infection in nine $(75.0 \%)$ of the twelve DPP seropositive dogs that remained alive during the follow-up period. This study is the first seroepidemiologic survey of CVL held in the city of Juiz de Fora, and the results reinforce the idea that this disease is currently in a process of expansion and urbanization in Brazil. Furthermore, this study highlights the use of the DPP test as an alternative for diagnosing CVL in large and mid-sized cities, due to its ease of implementation.
\end{abstract}

KEYWORDS: Canine visceral leishmaniasis; Serological diagnosis; Immunochromatographic diagnosis; DPP; PCR diagnosis.

\section{INTRODUCTION}

Visceral leishmaniasis (VL) is a potentially fatal protozoan vectorborne disease caused by the Leishmania donovani complex, and represents a serious risk to public health. This disease is endemic in 88 countries with approximately 0.2 to 0.4 million cases each year in Europe, South America, Africa and Asia (ALVAR et al., 2012). Anthroponotic transmission caused by L. donovani is present in the Indian subcontinent and in Central Africa, and zoonotic transmission caused by L. infantum is present in the Americas, Mediterranean basin, Middle East and Central Asia, and parts of Africa (HARHAY et al., 2011, PALATNIK-DESOUSA \& DAY, 2011).

Among the countries of the Americas, Brazil accounts for the highest number of human VL cases and is the third largest VL focus globally (ALVAR et al., 2012; BELO et al., 2013). Despite having presented a typical rural and wild pattern of VL until the 80's (WERNECK, 2008), current data show that the numbers have increased considerably, thus creating a new epidemiological profile, due to the spread of the disease to urban centers of the North, South and West regions of the country (JERONIMO et al., 2004; ROMERO \& BOELAERT, 2010; HARHAY et al., 2011). In Brazil, domestic dogs are the main reservoir, and thus play an important role in the epidemiology of the disease, while foxes and other wild animals play a role in sylvatic transmission (DEANE, 1956; QUINNELL et al., 1997; ROMERO \& BOELAERT, 2010). There is a clear positive correlation between human and canine infection rates, so that diagnosing dogs represents an important step towards the control of VL (GRIMALDI et al., 2012). The Brazilian Ministry of Health recommends both the immunoenzymatic assay (ELISA) and the indirect immunofluorescence antibody test (IFAT) as the chosen tests for dogs screening and culling campaigns. However, the moderate sensitivity and specificity of these tests together with the complexity of their implementation have been cited as factors of limited impact for the control of CVL (HARHAY et al., 2011; BELO et al., 2013).

In 2008, the first confirmed cases of autochthonous CVL were provided by the "Secretaria Municipal de Saúde" de Juiz de Fora, Minas Gerais State, Brazil (unpublished data). However, no research on this infection in dogs was carried out in the city. Considering the relevance of CVL in the epidemiology of human disease, this work was aimed at investigating its occurrence in the city of Juiz de Fora. Diagnosis of CVL was performed using the colloidal gold-based immunochromatographic

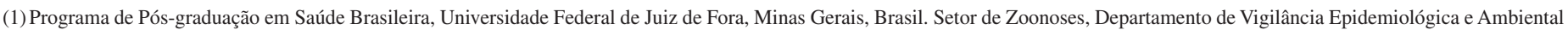
da Secretaria Municipal de Saúde de Juiz de Fora, Juiz de Fora, Minas Gerais, Brazil.

(2) Departamento de Parasitologia, Microbiologia e Imunologia, Instituto de Ciências Biológicas, Universidade Federal de Juiz de Fora, Juiz de Fora, Minas Gerais, Brazil.

(3) Laboratório de Pesquisa em Leishmaniose, Instituto Oswaldo Cruz, Fiocruz, Rio de Janeiro, RJ, Brazil.

(4) Laboratório de Tecnologia Diagnóstica, Biomanguinhos, Fiocruz, Rio de Janeiro, RJ, Brazil.

(5) Laboratório de Parasitologia, Departamento de Patologia e Parasitologia, Instituto de Ciências Biomédicas, Universidade Federal de Alfenas, Alfenas, Minas Gerais, Brazil.

Correspondence to: Elaine S. Coimbra, Tel.: +55 32 2102-3219, Fax: +55 32 2102- 3214. E-mail: elaine.coimbra@ufjf.edu.br 


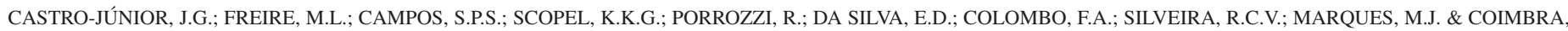
E.S. - Evidence of Leishmania (Leishmania) infantum infection in dogs from Juiz de Fora, Minas Gerais State, Brazil, based on immunochromatographic Dual-Path Platform (DPP®) and PCR assays. Rev. Inst. Med. Trop. Sao Paulo, 56(3): 225-9, 2014.

TR DPP ${ }^{\circledR}$ kit. This is a commercial chimeric recombinant protein named K28, based on fragments of antigens of K9, K26 and K39 of the Leishmania donovani complex (GRIMALDI et al., 2012). Additionally, conventional and/or real time PCR were used to detect and confirm $L$. infantum DNA in DPP positive dogs.

\section{MATERIAL AND METHODS}

Study area: This work was carried out in the municipality of Juiz de Fora (21S14/42W14), Minas Gerais State, Brazil. This city is a midsized urban center located $280 \mathrm{~km}$ from the State capital, Belo Horizonte, and $184 \mathrm{~km}$ from the city of Rio de Janeiro, which are considered to be endemic and of sporadic transmission to CVL, respectively (HARHAY et al., 2011).

Sample selection: This study comprised 400 dogs housed in the public kennel of Juiz de Fora, from December 2011 to July 2012. After immobilization of the animals, blood samples were collected by puncturing either the cephalic, brachial or jugular vein.

The samples were collected and distributed into tubes without anticoagulants to obtain serum after centrifugation (500x $g$ for 10 minutes) or collected into EDTA for further PCR diagnosis. In this case, after centrifugation of the blood samples at 500xg for 10 minutes, leukocyte layers were collected, alliquoted and stored in Tris-EDTA solution (1:1) at $-20{ }^{\circ} \mathrm{C}$ for later use.

Ethical clearance was obtained from the Institutional Review Board of the Federal University of Juiz de Fora, Brazil (CEEA\#03/2010).

Clinical examination: The dogs underwent a veterinary clinical examination and were classified according to MANCIANTI et al. (1988) in the following ways: symptomatic (cutaneous alterations, onychogryphosis, keratoconjunctivitis, hind-limb rigidity, etc); oligosymptomatic (lymphadenopathy, slight weight loss and/or hair opacity) and asymptomatic (absence of signs and symptoms referable to Leishmania sp infection).

Dual-Path Platform immunochromatographic test (TR DPP ${ }^{\circledR}$ ): Occurrence of L. chagasi, similar to L. infantum infection (GRIMALDI et al., 2012) was investigated by means of an immunochromatographic test manufactured as Dual-Path Platform CVL rapid test (TR DPP ${ }^{\circledR}$ Leishmaniosis Visceral Canina, Bio-Manguinhos, Rio de Janeiro, Brazil). This kit uses recombinant specific agents for the diagnosis of $L$. infantum infection (GRIMALDI et al., 2012), and it is being approved to be used in the Brazilian VL control program (ALVES et al., 2012). This ready-to-use disposable device is based on the reaction of colloidal gold particles coupled with the protein $\mathrm{A} / \mathrm{G}$ with the antigen bound to antibodies, which can be visualized after colored test band sample. To perform the exams, $5 \mu \mathrm{L}$ of serum from each animal were used, and the results analyzed after 15 minutes. In addition to visual evaluation, the results were also considered to be "positive" only after being read using the DPP optical reader device provided by the manufacturer (DPP Reader, ChemBio Diagnostic Systems, Inc, Medford, NY, USA). Serum samples from VL-positive and negative animals were used as controls.

PCR diagnosis: DNA extractions from peripheral blood leukocytes were performed using the phenol-chloroform-isoamyl alcohol method, as was described before (SAMBROOK et al., 1989). DNA obtained from L. infantum (MHOM/BR/1974/PP75; WHO reference strain) cultivated in a laboratory was used as a positive control in the molecular techniques. The DNA samples were analyzed using the Nanodrop ND100 (Thermo Scientific, CA, USA) and the absorbance was measured at 260/280 $\mathrm{nm}$ for the assessment of nucleic acids purity. The concentration was adjusted to $250 \mathrm{ng} / \mathrm{uL}$ for those samples with highest concentration (SAMBROOK et al., 1989). Experiments for conventional PCR were made using the following primer sets: presence of $L$. infantum in canine samples was determined by RV1-RV2 marker (5'CTTTTCTGGTCCCGCGGGTAGG3' and 5'CCACCTGGCCTATTTTACACCA3') (COLOMBO et al., 2011), which amplified a 145-bp product from the LT1 fragment of Leishmania donovani complex kDNA minicircles (RAVEL et al., 1995; LE FICHOUX et al., 1999; GOMES et al., 2007). The PCR conditions were as follows: an initial denaturation of five minutes at $94{ }^{\circ} \mathrm{C}$, followed by 30 cycles $\left(30\right.$ seconds at $94{ }^{\circ} \mathrm{C}, 30$ seconds at $60{ }^{\circ} \mathrm{C}$, and 30 seconds at $72{ }^{\circ} \mathrm{C}$ ) and a final extension of five minutes at $72{ }^{\circ} \mathrm{C}$. To check the success of DNA extraction control protocol the course of extraction and check for PCR inhibitors, all canine samples were assayed using the GAPDH 4 assay 5'AGGCTGAGAACGGGAAACTT3' and 5'ATTAAGTTGGGGCAGGGACT3' (KULLBERG et al., 2006), that amplified a 911-bp fragment of a canine glyceraldehyde-3-phosphate dehydrogenase. Reactions using the canine primer pair were run simultaneously in accordance with the same temperature protocol for the RV1-RV2 marker and in the same PCR machine. All positive PCR results for canine GAPDH confirmed the good quality of dog DNA extractions. After thermal cycling, the PCR products were electrophoresed in a $2 \%$ agarose gel and stained with ethidium bromide. The DNA fragments were visualized under UV illumination. The images were analyzed using a Mini Bis Gel Imager and Documentation (BioSystematics). Fragment sizes were estimated based on comparisons with a 100-bp ladder.

The LINJ31 primer set for a real-time PCR was designed using Primer Express ${ }^{\circledR}$ Software from Applied Biosystems and was based on the L. infantum hypothetical protein (partial mRNA; GeneBank accession number LinJ31.1310). The LINJ31 design is 5'CCGCGTGCCTGTCG3' and 5'CCCACACAAGCGGGAACT3', and the TaqMan probe, FAM dye-labeled, is 5'CCTCCTTGGACTTTGC3' (COLOMBO et al., 2011). The primer set had NFQ as a reporter quencher. Each PCR assay was performed by adding $5 \mu \mathrm{L}$ of DNA template and $25 \mathrm{pmol}$ of each primer, using a kit purchased from Promega (Go Taq Green Master Mix), and performed following the manufacturer's instructions. For each amplification reaction, both negative (ultrapure water and a canine DNA sample negative for leishmaniasis) and positive (DNA extract from $L$. infantum promastigotes) controls were used. Real time amplification of DNA reactions was performed using the Applied Biosystems (ABI 7500 Real Time PCR System) at a final volume of $20 \mu \mathrm{L}$ as described before (COLOMBO et al., 2011). Reactions were previously standardized using serial promastigote DNA dilutions as templates. The cycle threshold (CT) value was indicative of the amount of the target gene.

Statistical analysis: Statistical tests were carried out at a $5 \%$ significance level $(p<0.05, \mathrm{CI} 95 \%)$ and comparative analysis of positivity between the clinical groups was performed using Pearson's $\chi^{2}$ test. 


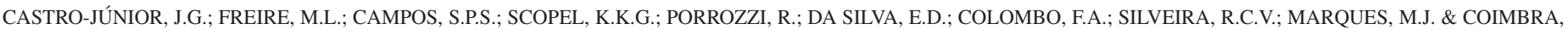

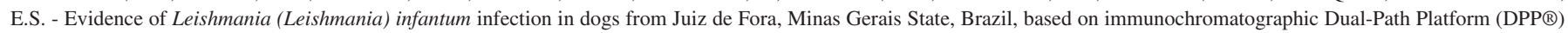
and PCR assays. Rev. Inst. Med. Trop. Sao Paulo, 56(3): 225-9, 2014.

\section{RESULTS AND DISCUSSION}

According to the $\mathrm{DPP}^{\circledR}$ immunochromatographic test, fifteen $(3.8 \%)$ of the 400 dogs investigated were CVL seropositive (Table 1). Although there have been reports of the occurrence of cases of autochthonous CVL in Juiz de Fora in 2008, the present work is the first seroepidemiologic survey concerning this disease ever performed in the municipality. However, it is not possible to be sure whether the CVL cases are autochthonous or not, since the study was carried out in dogs housed at a municipal kennel, meaning there is no background information.

\section{Table 1}

Comparative results obtained by TR DPP® (DPP) and/or conventional plus rea time PCR assays for detection of Leishmania infantum in clinical samples from dogs housed in the public kennel of Juiz de Fora, Minas Gerais State (Brazil) in 2012 .

\begin{tabular}{lccc}
\hline Clinical Group & $\begin{array}{c}\text { Dogs } \\
\mathrm{n}(\%)\end{array}$ & $\begin{array}{c}\text { DPP+ } \\
\mathrm{n}(\%)\end{array}$ & $\begin{array}{c}\text { PCR+ } \\
\mathrm{n}(\%)\end{array}$ \\
\hline Symptomatic & $45(12.5)^{\mathrm{a}}$ & $2(4.4)^{\mathrm{a}}$ & $1(2.2)$ \\
Oligosymptomatic & $78(21.8)^{\mathrm{b}}$ & $5(6.4)^{\mathrm{a}}$ & $1(1.3)$ \\
Asymptomatic & $235(65.6)^{\mathrm{c}}$ & $8(3.4)^{\mathrm{a}}$ & $7(3.0)$ \\
No Classified & $42(10.5)^{\mathrm{a}}$ & $0(0.0)$ & $0(0.0)$ \\
\hline Total & $400(100.0)$ & $15(3.8)$ & $9(2.3)^{*}$ \\
\hline
\end{tabular}

n: number of dogs; TR DPP®: Rapid Test Dual Path Platform; PCR: Leishmania infantum DNA detection by conventional and/or real time polymerase chain reaction; *PCR was run with twelve DPP positive samples. a, b, c: equal letters mean positivity indexes that are statistically similar; Chi-square test (significant at $p<0.05$ ).

Immunocromatographic tests using recombinant antigen have been cited by several authors for both human VL and CVL diagnosis (SUNDAR et al., 1998; ASSIS et al., 2008; DE LIMA et al., 2010; SRIVASTAVA et al., 2011, ROSYPAL et al., 2013). In Brazil, DPP assay was established as the screening test for CVL diagnosis in March 2012 (SIPAR- MS \#25000. 227.865/20011-11). Despite being an innovative, easy-to-use assay, in some cases we noticed a faint band, which is difficult to be discriminated through visual evaluation only. This fact was also reported by GRIMALDI et al. (2012). So, we decided to use a DPP optical reader device whenever there was a dubiety in the results.

Table 1 concerns clinical signs among the total number of samples ( $n=400)$, most $(89.5 \%)$ were classified as attributed to CVL. However, in some cases $(n=42)$ the dogs could not be examined, either because they died, fled from the kennel, or were donated during this study. Of the clinical signs that were analyzed among the remaining 358 samples, the total number (100.0\%) was classified as attributed to CVL. Indeed, 45 dogs (12.5\%) presented symptoms compatible with L. infantum infection, 78 $(21.8 \%)$ were oligosymptomatic and $235(65.6 \%)$ were asymptomatic $(p<0.05)$. Onychogryphosis was the most common symptom observed $(12.6 \%)$ (data not shown). Among the 15 DPP seropositive dogs, eight were considered asymptomatic, five oligosymptomatic and two symptomatic. However, there was no statistically significant difference between the DPP seropositive dogs and the clinical signs of the disease $(p>0.05)$.

GRIMALDI et al. (2012), using the same immunochromatographic test, observed that its sensitivity was significantly higher in animals with signs of CVL. According to ALVES et al. (2012), the sensitivity and specificity indices of DPP remained high, regardless of the inclusion or exclusion of the animals infected by Trypanosoma caninum. These findings highlight the practical use of this test as an alternative for CVL diagnosis.

Additionally, conventional and/or real time PCR assay was performed only in DPP seropositive dogs. Among the twelve DPP seropositive dogs which remained alive during the follow-up period, nine $(75.0 \%)$ were positive in the PCR analysis (Table 1 and Figure 1), suggesting the real occurrence of CVL in the municipality of Juiz de Fora. Indeed, PCR has the advantage of being a reliable technique for determining the presence of the parasite not only in active CVL, but also within asymptomatic dogs (QUEIROZ et al., 2010). It is interesting to note that of the eight asymptomatic dogs found positive in the DPP assay, seven were confirmed by PCR analysis (Table 1).

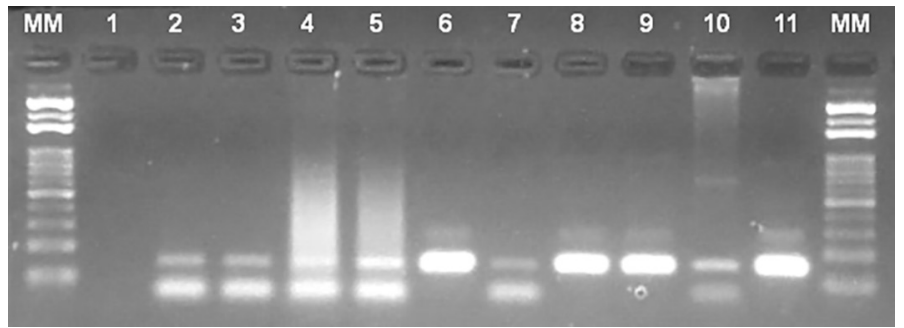

Fig. 1 - The electrophoresis $2 \%$ agarose gel shows the 145-bp products amplified by the $\mathrm{RV} 1 / \mathrm{RV} 2$ marker which is specific to a region of kDNA minicircles from the $L$. donovani complex. Lane 1 - Negative control; Lanes 2 to 10 - DNA samples extracted from DPP TRß positive dogs, 55, 180, 200, 209, 221, 222, 232, 261 and 339; Lane 11 - DNA from L. (L.) infantum (MHOM/BR/1974/PP75; WHO reference strain); MM - standard molecular size of 100-bp ladder.

Epidemiological studies on the occurrence of CVL in kennel dogs have been conducted in several parts of the world (CABEZON et al., 2010; BALDELLI et al., 2011; TÁNCZOS et al., 2012). Although kennels are not considered to be good epidemiological observatories in non-endemic areas, since they shelter abandoned dogs from all areas of the municipalities, on the other hand, kennel dogs can be considered important sentinels of some diseases, due to the risk of being exposed to pathogens and to not receiving any preventive or curative treatment during the free roaming period (CABEZON et al., 2010).

This is the first study of CVL caused by L. infantum held in the city of Juiz de Fora, and the results showed the prevalence of infected dogs, regardless of whether the CVL cases found were autochthonous or not. Furthermore, these results reinforce the idea that this disease is in the process of spreading and urbanizing in Brazil. Finally, our findings point to the need for active epidemiological surveillance in various regions of the country, including cities considered free areas for CVL, and confirm the DPP technology as a breakthrough in the detection of positive dogs in these areas.

\section{RESUMO}

Evidência de infecção por Leishmania (Leishmania) infantum em cães de Juiz de Fora, Minas Gerais, Brasil, detectada pelo teste imunocromatográfico rápido DPP e PCR

No Brasil, cães domésticos são considerados como os principais 


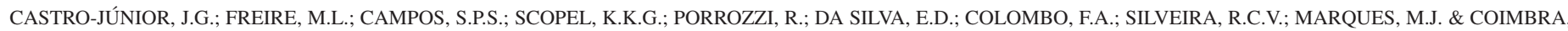
E.S. - Evidence of Leishmania (Leishmania) infantum infection in dogs from Juiz de Fora, Minas Gerais State, Brazil, based on immunochromatographic Dual-Path Platform (DPP®) and PCR assays. Rev. Inst. Med. Trop. Sao Paulo, 56(3): 225-9, 2014.

reservatórios da leishmaniose visceral zoonótica, devido à clara correlação positiva existente entre as curvas de infecção humana e canina. Este estudo objetivou a realização de um inquérito sorológico da leishmaniose visceral canina (LVC) em cães abrigados em um canil público de Juiz de Fora, Minas Gerais, Brasil, através do teste rápido imunocromatográfico TR DPP ${ }^{\circledR}$. Adicionalmente, a PCR convencional e/ou em tempo real foi usada para detectar/confirmar a infecção por $L$. infantum apenas nos animais DPP positivos. Dos 400 cães estudados, a maioria não apresentou sinais clínicos para a LVC $(p<0,05)$ e quinze $(3,8 \%)$ foram sororreativos ao DPP. Não houve diferença estatisticamente significativa entre os cães com DPP positivo e os sinais clínicos para a doença $(p>0,05)$. PCR convencional e em tempo real confirmaram a infecção por $L$. infantum em nove $(75,0 \%)$ dos doze animais DPP positivos que permaneceram vivos durante o estudo. Este é o primeiro estudo soroepidemiológico sobre LVC realizado no município de Juiz de Fora, e os resultados reforçam a idéia de que esta doença está em processo de expansão e urbanização no Brasil. Além disto, este estudo destaca o uso do DPP como uma alternativa para o diagnóstico da LVC em cidades de médio e grande porte, devido à facilidade de execução.

\section{CONFLICT OF INTEREST STATEMENT}

None of the authors of this manuscript have a financial or personal relationship with other people or organizations that could inappropriately influence or bias the content of the paper.

\section{ACKNOWLEDGMENTS}

We are grateful for financial support from FAPEMIG, CAPES, CNPq and UFJF. Our acknowledgements also go to the municipal authorities, especially to the team of the "Setor de Zoonoses/Departamento de Vigilância Epidemiológica e Ambiental da Secretaria Municipal de Saúde de Juiz de Fora", and to all kennel operators for their field support.

\section{REFERENCES}

1. Alvar J, Vélez ID, Bern C, Herrero M, Desjeux P, Cano J, et al. Leishmaniasis worldwide and global estimates of its incidence. PLoS One. 2012;7:e35671.

2. Alves AS, Mouta-Confort E, Figueiredo FB, Oliveira RV, Schubach AO, Madeira MF. Evaluation of serological cross-reactivity between canine visceral leishmaniasis and natural infection by Trypanosoma caninum. Res Vet Sci. 2012;26:1329-33.

3. Assis TS, Braga ASC, Pedras MJ, Barral AMP, Siqueira IC, Costa CHN, et al. Validation of the rapid immunochromatographic Test IT-LEISH $®$ for the diagnosis of human visceral leishmaniasis. Epidemiol Serv Saúde. 2008;17:107-16.

4. Baldelli R, Piva S, Salvatore D, Parigi M, Melloni O, Tamba M, et al. Canine leishmaniasis surveillance in a northern Italy kennel. Vet Parasitol. 2011;179:57-61.

5. Belo VS, Werneck GL, Barbosa DS, Simões TC, Nascimento BW, da Silva ES, et al. Factors associated with visceral leishmaniasis in the Americas: a systematic review and meta-analysis. PLoS Negl Trop Dis. 2013;7:e2182.

6. Cabezón O, Millán J, Gomis M, Dubey JP, Ferroglio E, Almería S. Kennel dogs as sentinels of Leishmania infantum, Toxoplasma gondii, and Neospora caninum in Majorca Island, Spain. Parasitol Res. 2010;107:1505-8.

7. Colombo FA, Odorizzi RM, Laurenti MD, Galati EA, Canavez F, Pereira-Chioccola VL. Detection of Leishmania (Leishmania) infantum RNA in fleas and ticks collected from naturally infected dogs. Parasitol Res. 2011;24:267-74.
8. Deane LM. Leishmaniose visceral no Brasil, estudos sobre reservatório e transmissões realizados no Estado do Ceará [tese]. Rio de Janeiro: Serviço Nacional de Educação Sanitária; 1956.

9. de Lima VM, Fattori KR, Michelin A de F, da Silveira Neto L, Vasconcelos R de O. Comparison between ELISA using total antigen and immunochromatography with antigen rK39 in the diagnosis of canine visceral leishmaniasis. Vet Parasitol. 2010;173:330-3.

10. Gomes AH, Ferreira IM, Lima ML, Cunha EA, Garcia AS, Araujo MF, et al. PCR identification of Leishmania in diagnosis and control of canine leishmaniasis. Vet Parasitol. 2007;144(3-4):234-41.

11. Grimaldi G Jr, Teva A, Ferreira AL, dos Santos CB, Pinto IS, de-Azevedo CT, et al. Evaluation of a novel chromatographic immunoassay based on Dual-Path Platform technology (DPP® CVL rapid test) for the serodiagnosis of canine visceral leishmaniasis. Trans R Soc Trop Med Hyg. 2012;106:54-9.

12. Harhay MO, Olliaro PL, Costa DL, Costa CH. Urban parasitology: visceral leishmaniasis in Brazil. Trends Parasitol. 2011;27:403-9.

13. Jeronimo SM, Duggal P, Braz RF, Cheng C, Monteiro GR, Nascimento ET, et al. An emerging peri-urban pattern of infection with Leishmania chagasi, the protozoan causing visceral leishmaniasis in northeast Brazil. Scand J Infect Dis. 2004;36:443-9.

14. Kullberg M, Nilsson MA, Arnason U, Harley EH, Janke A. Housekeeping genes from phylogenetic analysis of eutherian relationships. Mol Biol Evol. 2006;23:1493-503.

15. Le Fichoux Y, Quaranta JF, Aufeuvre JP, Lelievre A, Marty P, Suffia I, et al. Occurrence of Leishmania infantum parasitemia in asymptomatic blood donors living in an area of endemicity in southern France. J Clin Microbiol. 1999;37:1953-7.

16. Mancianti F, Gramiccia M, Gradoni L, Pieri S. Studies on canine leishmaniasis control. 1. Evolution of infection of different clinical forms of canine leishmaniasis following antimonial treatment. Trans R Soc Trop Med Hyg. 1988;82:566-7.

17. Palatnik-de-Sousa CB, Day MJ. One health: the global challenge of epidemic and endemic leishmaniasis. Parasit Vectors. 2001;4:197.

18. Queiroz NMGP, Assis J, Oliveira TMFS, Machado RZ, Nunes CM, Starke-Buzetti WA. Canine visceral leishmaniasis diagnosis by immunohistochemistry and PCR in skin tissues in association with RIFI and ELISA-test. Rev Bras Parasitol Vet. 2010;19:32-8.

19. Quinnell RJ, Courtenay O, Garcez L, Dye C. The epidemiology of canine leishmaniasis: transmission rates estimated from a cohort study in Amazonian Brazil. Parasitology. 1997; 115:143-56.

20. Quinnell RJ, Courtenay O, Garcez LM, Kaye PM, Shaw MA, Dye C, et al. IgG subclass responses in a longitudinal study of canine visceral leishmaniasis. Vet Immunol Immunopathol. 2003;10:161-8.

21. Ravel S, Cuny G, Reynes J, Veas F. A highly sensitive and rapid procedure for direct PCR detection of Leishmania infantum within human peripheral blood mononuclear cells. Acta Trop. 1995;9:187-96.

22. Romero GAS, Boelaert M. Control of visceral leishmaniasis in Latin America: a systematic review. PLoS Negl Trop Dis. 2010;4:e584.

23. Rosypal AC, Bowman SS, Epps SA, El Behairy AM, Hilali M, Dubey JP. Serologica survey of dogs from Egypt for antibodies to Leishmania species. J Parasitol. 2013;99:170-1.

24. Sambrook J, Fritsch EF, Maniatis T. Molecular cloning: a laboratory manual. $2^{\text {nd }}$ ed. Cold Spring Harbor: Cold Spring Harbor Laboratory Press; 1989. p. 9.14-9.23.

25. Srivastava P, Dayama A, Mehrotra S, Sundar S. Diagnosis of visceral leishmaniasis. Trans R Soc Trop Med Hyg. 2011;105:1-6 
CASTRO-JÚNIOR, J.G.; FREIRE, M.L.; CAMPOS, S.P.S.; SCOPEL, K.K.G.; PORROZZI, R.; DA SILVA, E.D.; COLOMBO, F.A.; SILVEIRA, R.C.V.; MARQUES, M.J. \& COIMBRA, E.S. - Evidence of Leishmania (Leishmania) infantum infection in dogs from Juiz de Fora, Minas Gerais State, Brazil, based on immunochromatographic Dual-Path Platform (DPP®) and PCR assays. Rev. Inst. Med. Trop. Sao Paulo, 56(3): 225-9, 2014.

26. Sundar S, Reed SG, Singh VP, Kumar PC, Murray HW. Rapid accurate field diagnosis of Indian visceral leishmaniasis. Lancet. 1998;351:563-5.

27. Tánczos B, Balogh N, Király L, Biksi I, Szeredi L, Gyurkovsky M, et al. First record of autochthonous canine leishmaniasis in Hungary. Vector Borne Zoonotic Dis. 2012;12:588-94.
28. Werneck GL. Forum: geographic spread and urbanization of visceral leishmaniasis in Brazil. Introduction. Cad Saude Publica. 2008;24:2937-40.

Received: 9 July 2013

Accepted: 24 September 2013. 